УДК 340.1

\title{
Др Марко Трајковић*
}

\section{ВРЕДНОСНА УСМЕРЕНОСТ ПРАВА НАСПРАМ ПРАВНОГ ПОЗИТИВИЗМА}

У овом добу технолошки захукталог позитивизма често се у правној науци могу чути тврдње да право треба да истисне вредности из себе и да постоји без юих. Та тврдња није нова. Ново је само објашњење због чега се то тврди. А оно гласи да се тиме право ослобађа људских слабости, постаје чисто научно засновано и вредносно неутрално као једна чисто реална појава живота. Као да се заборавило да прогламена вредносна неутралност права такође представља једну вредност. Због тога је умесније говорити о нужној вредносној усмерености права, заснованој на тврдњи да свако право тежи ка властитом самоусавршавању. То самоусавршавање нужно има као крајњи ииль претварање позитивног права у идеално, природно право. У том случају, одговор на питање да ли право може да постоји без вредности постаје јасан - не може. И не само да не може, већ се не сме ни тежити ка праву одвојеном од вредности. У противном, показала би се као тачна мисао Томе Аквинског да је право створено само због злих и опаких.

Вредности постојано утичу на право. Оне га установљавају, омогућавају стваране све бољег права и преко њега се остварују. Као такве, оне представљају поуздано полазиште за разумевање права и одређивање његовог појма.

Кључне речи: Вредност и невредност. - Право. - Правни позитивизам. - Морал.

* Аутор је ванредни професор Правног факултета Универзитета у Нишу, trajkovicmarko@yahoo.com.

** Овај чланак је резултат истраживачког рада у оквиру пројекта бр. 179046 „Заштита људских и мањинских права у европском правном простору“ Правног факултета у Нишу који финансира Министарство за науку и технолошки развој Републике Србије. 


\section{1. УВОД}

Развој правне науке изнедрио је две главне и међусобно супротстављене групе гледишта ${ }^{1}$ поводом питања „Шта је право?““. 2 До тога је дошло због различитих почетних полазишта која су довела у питање начелно општи став правника да је одређивање појма права од великог значаја. ${ }^{3}$ Правници због тога ,још увек траже дефиницију за свој појам права“". ${ }^{4}$

Настојећи да одреде право и његов однос према вредностима, обе групе гледишта су се још више удаљиле једна од друге.

Прва група „прати главну сврху укупне јуриспруденције“ и њену „примену на стварни живот“, али у исто време гради „свој стан у кодексу позитивних закона“" у којем не станује, већ је његов заточеник који се не усуђује да „гледа преко његових високих зидова“. 5 Будући да за правни позитивизам право не представља мистерију, ${ }^{6}$ а „закон је закон“" (Gesetz ist Gesetz), то се извор права проналази у вољи владара, ${ }^{7}$ тј. држави и њеној сили, као последњем ауторитету који праву обезбеђује обавезујућу снагу. Речју, право свој извор има у аргументу силе. То дозвољава да се закључи како се може одбацити свако право које није створено „људским прописом“. 8

Друга група гледишта државу не схвата као свог идола или „смртног Бога“. Сматрају да су право и држава средства за постизање већих вредности и одбацују „формално важеће право у корист онога које филозофски важи“.9 То дозвољава да се закључи како је могуће постојање другачијег права од оног које важи само формално. ${ }^{10}$

1 Изгледа да су супротстављена схватања у правној науци нужна последица „раздвајања мислећег дела људског рода на две супротстављене стране чија су се основна схватања свагда међусобно борила, а зацело никада неће ни престати да се нападају“ (Ј. Ј. Банхофен, Природно право и историјско право, Досије, Београд 2008, 5). Вид. Д. М. Митровић, Теорија државе и права, Досије студио, Београд 2010, 244-358.

2 C. Johnson, Philosophy of Law, New York 1993, 1.

3 Ibidem.

4 Вид. И. Кант, Критика чистог ума. Нав. према: Ј. Биндер, Прилог учеґу о појму права, Досије Београд 2008, 5.

5 А. Фојербах, Однос филозофије и емпирије према позитивној правној науuи, Досије, Београд 2008, 8 .

45.

6 O. W. Holmes, Jr., The Path of the Law, y: C. Johnson, Philosophy of Law,

7 St. T. Aquinas, Treatise on Law, Excerpts from Treatise on Law, Questions 90-91, 94-96 of Summa Theologica y: C. Johnson, Philosophy of Law, 14.

8 К. Шмит, Три врсте правнонаучног мишьења, Досије, Београд 2003, 24.

9 А. Фојербах, 9.

10 St. T. Aquinas, 90-91, 94-96, y: C. Johnson, 14. 
Изгледа да је немогуће постићи сагласност између ових двеју страна. Тиме као да се потврђује мисао Јозефа фон Штала (Joseph von Stahl) по коме „Између страна које стоје непријатељски једна према другој“ никако „нема измирења, нема средине“. Једноставно, не може „Постојати савез између вере и невере, између истине и заблуде“." И обратно: „Ваши разлози нису разлози за мене; ви ово признајете као право, а ја по мојој филозофији као оно; оно што ви по своме уму називате злочином, по моме је правда“. ${ }^{22}$ Таква искључивост, очигледно, уништава особени карактер права. Нарочито је важно да се не превиди право због вредности (вредносни смисао права) нити вредности због права (правни смисао вредности). То је разумљиво, јер само вредности праву прибављају „минималну меру““13 по којој оно може да одређује и „мери своје удаљавање од савршеног или приближавање њему“? ${ }^{14}$

\section{2. РАЗАРАЬЕ ВРЕДНОСНОГ СМИСЛА ПРАВА}

Фебруара 1906. године, Херман Канторович (Herman Kantorowicz), под псеудонимом Gnaeus Flavius, овако описује правника: то је „виши државни чиновник с академским образовањем, седи у својој собици наоружан само једном машином за мишљење, наравно, једном од најизврснијих. Једини намештај те собице јесте један зелени сто на којем пред њим лежи државни законик. Човек му даде какав било случај, стварни или измишљени, и сходно својој дужности он ће бити кадар да помоћу чисто логичких операција и једне тајне технике, само њему схватљиве, с апсолутном егзактношћу покаже решење које је законодавац претходно одредио у законику““. ${ }^{15}$ Овом опису „специјалисте без духа и маште“, ${ }^{16}$ данас се може додати само рачунар који стоји испред истог државног чиновника који нема потребу за вредносним судовима и одлукама, већ само за текстом закона који не испитује и слепо га следи, те није ништа друго до „егзегет и компилатор појединих закона, чије одредбе марљиво сакупља, у најбољем случају оскудно сређује, али за сваки случај чува само као

11 J. Stahl, Die Philosophie des Rechts nach geschichtlicher Auffassung, 2. Bd., I. Abt., Heidelberg 1883, VI. Нав. према: J. J. Банхофен, 6.

12 А. Фојербах, 15.

13 Бенедикт XVI, енцилика Љубав у истини, Београдска надбискупија, Београд 2010, 10.

14 А. Фојербах, 40.

15 Х. Канторович, Борба за правну науку, Досије, Београд 2006, 7.

16 L. Strauss, Natural Right and History, The University of Chicago Press, Chicago \& London 1992, 42. 
благо за једно марљиво верно сећање“. ${ }^{17}$ Занима га оно што јесте, и све што му треба налази се само у закону. Поставка о „нормативној снази фактичкога“ ${ }^{18}$ којом је могуће чак и „уставне празнине“ попунити „односима фактичке моћи,“" чини му се привлачном ${ }^{19}$ и у исто време једино разумном, док су све остале обмана. Очигледно му је да позитивноправна наука тежи да право сазна онакво какво оно стварно јесте, а не онакво какво би требало да буде по нечијем вредносном суду. А и тај суд, најчешће искривљен према позитивистичком схватању, испуњен је терминолошком збрком, док је право препуно моралне фразеологије. ${ }^{20}$ Претерана и олака употреба аксиолошких поставки и вредносних израза за позитивисте је не само неупотребљива већ и штетна приликом доношења, тумачења и оцењивања правних прописа. ${ }^{21}$ Они сматрају да смисла има „нормативна мотивациона снага права“"22 а не морална вредност. Због тога, правни позитивисти желе да спрече повезивање права са вредностима.

Позитивистичка мисао достиже врхунац у нормативистичком учењу Ханса Келзена (Hans Kelsen) који сматра да правну науку треба ослободити свих елемената који су јој страни, нарочито је треба одвојити од морала и правде, јер право мора да се сазна онакво какво јесте, ${ }^{23}$ „не лигитимирајући га као праведно или дисквалификовати га као неправедно...“.24 За правни позитивизам је нарочито важно да се ослободи правне аксиологије, јер само у том случају позитивном праву може да се прида апсолутна вредност на коју полажу право моралне вредности. Ипак, чак се и Келзен слаже са тим да се „мисао о апсолутној вредности права не губи сасвим, она живи и даље у етичкој идеји правде, које се придржава и позитивистичка јуриспруденција“. ${ }^{25}$

Према позитивистичком гледишту, вредносни судови су субјективно-ирационалне природе, те их је немогуће применити у

17 А. Фојербах, 8.

18 К. Шмит, 29.

19 Ibid., ф. 20, 29.

20 O. W. Holmes, Jr., The path of the Law, y: C. Johnson, Philosophy of Law, 47.

21 Према Џону Остину, право је заповест издата подређенима (J. Austin, Law as the Sovereing 's Command, from: The province of Juriprudence Determined, y: C. Johnson, Philosophy of Law, 37).

22 К. Шмит, 29.

23 Нарочито је Келзен наглашавао да, осим нормативистичке, свака друга дефиниција права мора да буде одбачена (H. Kelsen, Law as a Normative Order, from: The Pure Theory of Law, 1967, y: C. Johnson, Phisisophy of Law, 66). ду, 1998, 19.

24 Х. Келзен, Чиста теорија права, Правни факултет Универзитета у Београ25 Ibid., 21. 
правној науци. Овакво становиште у најрадикалнијој верзији заузима Ричард Поснер (Richard A. Posner), који тврди да филозофија морала нема шта да понуди ученим правницима или судијама у доношењу пресуда или стварању правних доктрина. По његовом мишљењу, образовани људи који су прихватили учење филозофије морала, за разлику од оних који нису под њеним утицајем, понашају се мање морално. Морално теоретисање не ствара добру основу за моралне судове и не може од нас начинити боље људе. ${ }^{26}$ Чак и када би оно створило ваљану основу за моралне судове, они не би смели да буду употребљени приликом доношења правних одлука јер изазивају забуну. ${ }^{27}$ Ни познавање морала не може да нас покрене или да створи мотивацију за делање. Та мотивација мора да се пронађе изван морала. Произилази да је морал облик социјалне контроле који има мањи утицај на људе него што се мисли. Сагласно са тим, правна питања не би требало проучавати из угла филозофије морала, већ из угла једног прагматичког становишта лишеног веровања у ванвременске и ванпросторне моралне вредности. То становиште Поснер назива прагматички морални скептицизам.

\section{3. ПОВЕЗИВАЬЕ ВРЕДНОСТИ СА ПРАВОМ}

Можда је најближе истини када се каже да вредности указују на снагу закона записаних у нашим срцима. ${ }^{28}$ Оне у исто време „побуђује чежњу, отварају нову могућност... “. ${ }^{29}$ И све покрећу, па и право. Исту идеју, засновану на сврси коју вредности испољавају, развио је Херман Лоце (Herman Lotze). Он сматра да се моћ тог „прапочетка“" налази у вери, чиме прихвата теолошки идеализам. ${ }^{30}$ Самим тим, стварност света и стварност права подређују се вредностима које оличава Творац. ${ }^{31}$ То значи да је њихово важење апсолутно, а не „Половично“ или „делимично“. 32

Постоји и феноменолошка аксиологија, унутар које треба издвојити учење Макса Шелера (Max Scheler). Шелер у свом учењу истрајава на постојању вредности које су дате унутар наше ствар-

\footnotetext{
26 R. A. Posner, The Problematics of Moral and Legal Theory, London 2002, 3.

27 Ibid., 6.

28 St. T. Aquinas, Treatise on Law, in: C. Johnson, Philosophy of Law, 16.

29 T. Matulić, Metamorfoze kulture, Glas Koncila, Zagreb 2009, 393.

30 В. Павићевић, Однос вриједности и стварности у модерној юемачкој идеалистичкој аксиологији, Култура, Београд 1958, 18.

31 „Ако се осврнемо на људски живот, видећемо да морално настаје из религије и мита““ (А. Либерт, Идеја моралнога, Досије, Београд 2006, 5).

32 Више о Лоцеовом схватању вредности вид. H. Lotze, Mikrokosmos, I, II, III,
} Leipzig 1923. 
ности, те су самим тим искуствено доступне и постављене унутар вредносног онтологизма. ${ }^{33}$ По њему, вечност вредности указује на њихов апсолутни ред. То важи и за људске творевине које су све засноване на ,вредности једног бесконачног личног духа и света вредности који лежи пред њим“. ${ }^{34}$ На пример, одређивањем правне норме утврђује се место права у свету вредности. Ако се не жели да норма остане произвољна заповест, она мора свој основ да нађе у вредностима а не у покорности субјеката. Због тога су вредности „најједноставнији квалитети“ који одређују смисао норми и права. ${ }^{35}$ Разлог је једноставан: свет вредности је „постојбина“ права.

На начин сродан Шелеровом поступа Лоце у свом учењу, а готово да је исто учинио и Хартман када је записао да „етика мора у себи садржавати и последње утемељење права, мора у својој таблици вредности показати место за вредност права уопште“. ${ }^{36}$

Наведена учења о вредностима могу се применити и на друге стране живота. У ствари, готово да се подразумева како „сва подручја духовног живота која садрже било какве етичке проблемске мотиве, било каква вредновања, стајалишта, тенденције или важеће одредбе практичке нарави, за етику морају бити значајни, за етику као ризницу феномена“. ${ }^{37}$ То важи и за право које „поседује чврсто сковани, егзактни појмовни систем“. ${ }^{38}$ Очигледна вредносна оријентација права не може се оспорити ни због „правности права као вредносног момента у правном феномену“. 39 Дакле, проблем одређивања места права у свету вредности спада у претходне, „претправне“ проблеме, јер право мора да буде засновано на „истински сагледаној вредности“.40 Свет вредности постаје претпоставка за постојање и развој права, док вредности ,испуњавају смислом и сврхом целокупно право, тј. све друге његове елементе“. ${ }^{41}$ Све то под условом да свет вредности као „постојбина“ права није „пуки збир, као што је случај са простим скупом елемената, већ целина“" ${ }^{42}$

33 В. Павићевић, 64-65.

34 M. Scheler, Fromalismus in der Ethik und die materiale Wertethik, 3 aufl., Haale 1927, 94. Нав. према: В. Павићевић, Однос врједности и стварности у модерној юемачкој идеалистичкој аксиологији, 83.

35 M. Scheler, Fromalismus in der Ethik und die materiale Wertethik, 272. Нав. према: В. Павићевић, 75.

36 Ibid., 71.

37 N. Hartmann, Etika, Naklada Ljevak, Zagreb 2003, 70.

38 Ibidem.

39 М. Перовић, Етика, Нови Сад 2001, 433.

40 N. Hartmann, 71.

41 Д. М. Митровић, Теорија државе и права, 530.

42 Ibidem. 
Упркос настојању позитивиста да право одреде као појам који је слободно постављен у односу на вредности или у односу на „сплет“ стварности и вредности, може се запазити како право нужно стиче свој вредносни садржај. Чак и позитивно право ,јавно сведочи за своју повезаност с вредношћу“. ${ }^{43}$ Због тога се на право са тако одређеним садржајем могу применити категорије вредносне оријентације. Штавише, одређење правне норме дешава се унутар света вредности и ума који вреднује, јер ми стојимо „пред деловањем примарне вредносне свести о праву“. ${ }^{44}$ Због тога се правна норма може одредити и као једна логички обавезујућа формулација вредности.

Право „почива на вредносним одређењима“ и због тога што тежи да постане идеално. ${ }^{45}$ Та тежња показује правац његовог развоја. Тек када се вредности установе, оне се могу изразити у облику правне норме која је нужно у служби вредности. На тај начин, правна норма формулише неку вредност или више њих у исто време. Али, то само по себи није довољно. Према Артуру Кауфману (Arthur Kaufmann), правна норма није драгоцена сама по себи, већ само ако изражава „изворне“ вредности. Да би норма стекла обавезујућу снагу она мора бити логична формулација која тачно и примерено преноси садржај вредности „у савест оних који су правно обавезни“. ${ }^{46}$ Та реч - „савест“, показује да правна норма, до чијег нам је „обавезујућег карактера“" стало, може да се „образложи само морално, само из њеног обавезујућег дејства на људску савест (чиме, међутим, не треба тврдити да су право и морал једно)“. ${ }^{47}$ Такође, човек је биће које тражи „посреднике“ приликом долажења до вредности и њиховог остваривања. Он у својој стварности вредности често не достиже непосредно. На тај начин, вредносно одређена правна норма може да постане „посредник“ и једна врста пута за долажење истих или других вредности. То потврђује сам поступак објективизације вредности нормама. Када се боље размисли, произилази да право постаје „мост“, који повезује вредности и конкретно владање. Право изражава садржај вредности и предлаже облик идеалног владања. И још нешто: та чињеница дозвољава да се говори о вредносној страни права као степену „осетљивости“ (енфорсибилитета) права према вредностима или као степену остваривања вредности у праву и путем права.

Право објективно преноси вредности и усмерава прописе ка њима. Захваљујући томе, вредности бивају остварене у нашој стварности. Оне спречавају да се овлашћења и дужности које право прописује изгубе у „празнини“ позитивизма који истрајава на томе

43 N. Hartmann, 71.

44 Ibidem.

45 D. Vrban, Država i pravo, Golden marketing, Zagreb 2003, 233.

46 А. Кауфман, Право и разумевање права, Београд-Ваљево 1998, 200.

47 Ibidem. 
да покоравање не може бити условљено „знањем о правности или неправности закона“. 48 Упркос „претензији“ права на убедљивост, уверљивост и обавезност, оно мора да пронађе своје место у свету вредности. Последица је следећа: „скретање са те потраге... наноси велику штету праву, доводи до подозривости и коначно до његовог одбацивања“. У том случају, право више није „слика“ вредности већ израз људске самовоље. ${ }^{49}$

Одређивањем вредности може се одредити место права у њиховом систему. Према Емилу Ласку (Emil Lask) правне норме могу се извести из апстрактних формула вредности. ${ }^{50}$ Затим би требало те „надемпиријске вредности (überempirischer Werte)“, како их Ласк назива, претворити у „самосталне животне силе (realen selbstängdigen Lebensmächten)“.51 То се може постићи ,уношењем“ вредности приликом стварања и примене права, чиме оне могу да постану стварно делотворне. На тај начин, право стиче своје трансцендентално место (treanszendentalen Ort) у свету вредности. ${ }^{52}$ У стварном свету, оно се односи само на оне појединце који не испуњавају неку вредност сами од себе. ${ }^{53}$

Иако се право може сматрати производом човека, оно се као такво може одредити и прихватити тек када је засновано на идеји која га повезује са његовом сврхом или када се односи на понашање повезано са вредношћу. ${ }^{54}$ Само вредности могу да сачињава идеју права. Оне су „грађа за идеју“, у овом случају, грађа за идеју права чији је смисао да служи вредности. И обратно, постојање права није могуће ако је оно „слепо за вредности“.55 Штавише, целокупно наше постојање заснива се и одржава уз помоћ вредности које служе као вечити стандарди понашања. ${ }^{56}$ Само вредности могу да „подаре“ обавезујућу снагу правним нормама, ${ }^{57}$ јер само оне имају „,стваралачку моћ“. То нарочито важи за моралне вредности. Захваљујући њима,

48 А. Фојербах, 17.

49 Вид. J. Ratzinger-Benedetto XVI, Europa, I suoi fondamenti oggi e domani, Città dell Vaticano 2004.

50 E. Lask, 283.

51 Ibid., 280.

52 Ibid., 286.

53 Ibid., 340.

54 G. Radbruch, Rechtsphilosophie, Verlag Von Quelle \& Mezer in Leipzig, Leipzig 1932, 4.

55 Ibid., 4, 29.

56 О односу вредности и понашања вид. В. Reich, C. Adcook, Values, Attitudes and Behaviour Change, Methuen, London 1976.

57 О проблему обавезујуће снаге правне норме вид. Р. Лукић, Обавезујућа снага правне норме и проблем објективног права, Завод за уџбенике и наставна средства, Београд 1995. 
може се захтевати да право испуњава „етички минимум“ (etische Minimum), како тврди Георг Јелинек (Georg Jellinek), ${ }^{58}$ и да се усмери ка вредностима и њиховом остваривању.

Постоји и вредносни пут права. Он представља једну врсту „борбе за право“.59 За аксиолошки приступ је неприхватљиво становиште правног позитивизма према коме се свако посматрање правне вредности проглашава ненаучним, при чему се свесно застаје на емпиријском истраживању права. Вредносни пут права је потребан да би се уклониле магле које су толико дуго стајале на путу разумевања права. Сагласно са тим, није могуће прихватити позитивистичке тврдње да ће правна стварност истиснути правне вредности. ${ }^{60}$ Нарочито је важно да правна наука описује, објашњава, критички оцењује и предлаже вредносне садржаје правног поретка, а не да то препусти случају или вољи власти, и тиме одбаци свако правно вредновање. ${ }^{61}$ Ни данас, правно вредновање и вредносно посматрање нису у ништа мањој мери филозофска потреба и темељ права. ${ }^{62}$

Вредности показују и својеврсно „аксиолошко лице права“. Односе се на његову суштину а не форму, која није довољна да образложи истинско порекло обавезујуће снаге права. Вредности морају да установе правила, а право мора да постане имперсонално, везано за објективне вредности, а не за интересе. ${ }^{63}$ Такође, потребно је изградити пожељан „вредносни менталитет“. Њега човек може да прихвати или одбије, али то неће смањити ни срушити ауторитет вредности. Може се рећи да управо тада вредности помажу праву да изрони из стварности. То важи и за друге друштвене науке. ${ }^{64}$

Одбијање да се користе вредносни судови доводи до дескриптивног изражавања и прикривања изворног знања. За означавање таквог „научног“ поступка Лео Штраус (Leo Strauss) користи Веберов израз „интелектуално непоштење (intellectual dishonesty)“. Очигледно, искључивост правног позитивизма или, да се овом приликом искористи Штраусов израз: „горка сатира (bitter satire)“, 65 омогућила је да се у правној мисли много тога прикрије о природи права.

58 G. Radbruch, 42-43.

59 Делом Борба за правну науку (Der Kampf un dei Rechtswissenschaft) Херман Канторович стварно започиње своју борбу за право (Ibid., 45). Исто је поступио Рудолф фон Јеринг, говорећи о борби за „морално самопотрврђивање“.

60 Ibid., 16, 21.

61 Према Радбруху, то је први утисак који остаје иза „читања“ програма историјске школе која као да одбацује свако правно вредновање.

62 Х. Канторович, 21.

63 О питању интереса вид. V. Zsifkovits, Politk ohne Moral?, VERITAS-Verlag, Linz 1989.

64 L. Strauss, 40.

65 Ibid., 52. 
Истрајавањем на истискивању или одбацивању вредности из права, правни позитивизам угрожава властиту историјску објективност и ускраћује себи могућност да осветли правну појаву у њеној укупности. ${ }^{66}$ Због тога није способан да разликује вредности од невредности и „добро“ право од „рђавог“ права.

\section{4. ЗАКЉУЧАК}

Изгледа да се и у праву догодило исто оно што се догодило самом човеку: попримило је „карактер саморазумљивости“",67 самодовољности и самодопадљивости, а то је довело до његовог „механичког окамењивања“".68 Тако се произвело супротно од жељеног: уместо да подстакне самоостваривање појединаца, то самостварење се правом додатно угрожава. ${ }^{69}$

Како год било, право не може бити препуштено „човековој субјективности““. ${ }^{70}$ Таква вредносна поставка, која пркоси саморазумљивости права, може се назвати „филозофијом без фелера“. Она представља и реакцију на тврдњу да не постоји „филозофија права, осим као филозофија позитивног права““71 Такође, она је одговор на „идеологију зла“"72 која неуморно цвета и вреба на онај исти начин на који ђаво „вреба у заседи на моралну равнотежу човека“. ${ }^{73}$ Све то би водило ка „неиздрживом слому“774 да није питања које одувек поставља моралан човек: „који закони важе и зашто“?” 75 Из овога следи да би филозофија вредности морала да буде још одређенија „брана“ данашњој преовлађујућој технократско-позитивистичкој идеологији. То увића и Густав Радбрух (Gustav Radbruch) током свог, како то Кауфман назива - „искуства пред Дамском““ ${ }^{76}$ Треба запам-

66 Ibid., 61, 63-64.

67 M. Scheler, Položaj čovjeka u kozmosu, Veselin Masleša - Svjetlost, Sarajevo 1987, 125.

68 L. Strauss, 42.

69 E. W. Böckenförde, Der Staat als sittlicher Staat, Dunker \& Humbolt, Berlin 1978, 24. $136-137$.

70 H. Jonas, Das Prinzip Verantwortung, Suhrkamp, Frankfurt am Mein 1984,

71 Г. Фасо, Историја филозофије права, ЦИД, Подгорица 2007, 548.

72 О „идеологији зла“ вид. J. Pawel II, Pamięć i tożsamość, Città dell VaticanoMilano 2005.

73 J. Ratzinger, V. Messori, Razgovor o vjeri,VERBUM, Split 2001, 128.

74 Из енциклике папе Лава XIII, под општом ознаком Eternae patris. Нав. према: А. Либерт, 28.

75 А. Либерт, 35.

76 A. Kaufmann, Uvod v filozofijo prava, Cankarjeva založba, Ljubljana 1998, 122. 
тити: право припада „царству духа или слободе, царству смисаоних творевина, стварности условљене вредностима, обликоване према идејама“. ${ }^{77}$ Али, право припада и вредностима које му омогућавају узлет, јер је историја показала да оно само не може да достигне постављене циљеве и обезбеди човеков опстанак. ${ }^{78}$

Може се закључити следеће: да позитивно право не би постало „дрвена глава без мозга“",79 увек се мора запитати „шта је долично“, а не само „шта је дозвољено“. 80 Задатак позитивног права је утолико тежи јер треба да „обезбеди да доброта буде безбедна чак и међу злотворима“. 81 Из тог разлога, вредности морају доследно да испуњавају позитивно право, да образлажу и обезбеђују његову обавезујућу снагу, док само право исте вредности мора да изражава и штити. Вредности од свих нас захтевају да чинимо добро, јер све још није уређено. ${ }^{82}$

Таква доследност у погледу вредности није везана само за право као некакав затворен и самодовољан систем. Она треба да буде динамична, а ипак верна репродукција доброте коју смо примили. ${ }^{83}$ Тамо где ,законодавац говори, филозофија, наравно, мора да заћути, али тамо где он ћути, ту она улази у своја стара права; где он својом живом речју не даје тумачење умног закона, ту она мора да заузме његово место и осветли својом буктињом оно што је његовом оку остало скривено“. ${ }^{84}$ На тај начин „празне формуле норми морају да се испуне садржајем проживљеног живота, односно оно што треба да буде мора да се тесно прожме с оним што јесте... идеја мора да се претвори у стварност“. 85 Тек преко вредности, праву може да се пружи толико преко потребна обавезујућа снага и потпуно оправдање, које није засновано на голој сили.

Може се рећи како право у додиру са вредностима умирује своје властито „Ја“. Оно се више не заснива на моћи и обавези, већ на нечем непропадљивом - на вредностима које су његова узданица, духовна суштина и „пут према истинском развоју““. ${ }^{86}$

77 Ј. Биндер, 31.

78 Бенедикт XVI, 19.

79 J. Ј. Банхофен, 7.

80 Г. Фасо, 583.

81 Ibid., 203.

82 Вид. В. Häring, Das Gesetz Crhisti I, Münich-Freiburg 1967.

83 Бенедикт, XVI, 20.

84 А. Фојербах, 37.

85 Ravà, Lo Stato come organismo etico, y: Diritto e Stato nella morale idealistica, 133-134. Нав. према: Г. Фасо, 584.

86 Бенедикт XVI, 94. 
Dr. Marko Trajković

Associate Professor

University of Niš Faculty of Law

\section{VALUE-ORIENTATION OF THE LAW VS. LEGAL POSITIVISM}

\section{Summary}

The law cannot squeeze out values. Thus, it comes as an imperative of our reality to set the place for the law in the world of values. The world of values is not apart from our reality. In our reality the world of values is the purpose of everything that exists. Actually, it is about the demand to bring values into our reality. The meaning of values is absolute. The eternity of values immediately points to the absolute order of values, which as such has its „homeland“ in Creator. The issue of finding the place of the law in the world of values is a „pre-legal“ issue. Thereby the world of values is becoming the assumption of the existence and development of the law. Legal norm then becomes the formulation of values. Legal norm is not precious in itself, but only if it expresses fundamental values. Legal norm has to be the logical formulation, that is to say, it has to deliver the contents of value correctly and appropriately. As an expression of the value dimension legal norm obtains the binding power. Keeping in mind the legal norm defined in such a way, nobody can deny its necessity in reality. The law then expresses the contents of value and proposes the model of the ideal behavior. The fact that values have „creating power“ is thus proved to be true.

Key words: Value and No-value. - Law. - Legal positivism. - Moral. 